\title{
Penerapan Acceleration Factor terhadap Karakteristik Citra Diagnostik T2WI FSE pada MRI Lumbal Kasus Herniated Nucleus Pulposus (HNP)
}

\author{
Ildsa Maulidya Maulidya ${ }^{1)}$, Gatot Murti Wibowo ${ }^{1)}$, Emi Murniati ${ }^{2)}$ \\ ${ }^{1)}$ Program Pascasarsajana, Magister Terapan Kesehatan Imaging Diagnostik Poltekkes Kemenkes Semarang, \\ Indonesia \\ 2) Jurusan Teknik Radiodiagnostik dan Radioterapi Poltekkes Kemenkes Semarang, Indonesia \\ e-mail : ildsamaulidya2608@gmail.com
}

Received: Mey 31th, 2019; Revised: June 30th, 2019; Accepted: July 9th, 2019

\begin{abstract}
Background: Patients with Herniated Nucleus Pulposus (HNP) cases have a bigger chance to do a movement during MRI examination. The technique of parallel imaging is a technique that can increase the speed of MRI data acquisition by passing through several lines of phase encoding in k-space. The GRAPPA technique is one of the methods to reconstruct data on MRI with better overall image quality. The purpose of this research is to know the difference of diagnostic image characteristic which is resulted in applying acceleration factor 2, 3, and 4 in parallel imaging of GRAPPA method and know the optimal acceleration factor to obtain MRI image of lumbar HNP case.

Methods: This research is quantitative research with descriptive approach. The study was conducted by MRI Siemens 3 T. The data were 30 MRI images of lumbar sagittal of HNP cases on T2WI FSE with acceleration factor 2, 3, and 4 GRAPPA methods.

Result: The results of this study indicate that there are differences in diagnostic image characteristics in the application of acceleration factor 2 and 4, 3 and 4 with the VGA test. Acceleration factor value optimal with VGC test known is acceleration factor 2 and 3.

Conclusion: Based on the result there were different diagnostic image characteristics of MRI Lumbar in sagittal plane Fast Spin Echo (FSE) sequence with variation acceleration factor 2, 3 and 4 parallel imaging GRAPPA method in case HNP. The optimal value of variation acceleration factor for MRI Lumbar examination of HNP is 2 dan 3.
\end{abstract}

Keyword: Acceleration Factor; lumbar MRI; T2WI FSE; HNP

\section{Pendahuluan}

Pasien dengan kasus HNP tidak dapat berbaring lama saat dilakukan pemeriksaan MRI karena tidak bisa menahan rasa sakit. Sehingga meyebabkan pasien bergerak selama pemeriksaan dan menghasilkan citra yang tidak optimal. Ketidak optimalan ini menyebabkan terjadinya pengulangan dalam pemeriksaan, sehingga diperlukan waktu yang cepat untuk menghasilkan citra yang baik. Pada kasus HNP pasien yang tidak dapat menahan rasa sakit,maka dalam pemeriksaan diperlukan waktu yang cepat dalam menghasilkan suatu citra MRI untuk keperluan diagnostik (Notosiswoyo \& Suswati, 2004). Dalam decade terakhir, salah satu cara untuk menurunkan waktu pemeriksaan (scan time) adalah dengan teknik parallel imaging. Parallel imaging MRI merupakan teknik canggih untuk meningkatkan kecepatan akuisisi data MRI dengan melewati beberapa garis phase encoding padak-space dengan arah frekuensi encoding yang tetap disampling penuh (Wang \& Al, 2010). Teknik parallel imaging memiliki parameter khusus yang dinamakan acceleration facto $r$ dan g-factor. Acceleration factor (R-factor) ini menyatakan jumlah elemen phased array coils yang akan mempengaruhi scan time (Blaimer \& Al, 2004). Dalam aplikasi klinis, penggunaan teknik parallel imaging pada MRI memungkinkan mendapatkan memungkinkan pengurangan waktu pemeriksaan yang signifikan pada urutan acceleration factor 2 atau acceleration factor 3 . Faktor akselerasi adalah jumlah elemen coil, menggambarkan kemampuan dengan konfigurasi coil yang digunakan untuk memisahkan piksel (Bert, 2007). Penggunaan acceleration factor yang lebih tinggi dalam metode pencitraan parallel biasanya diikuti dengan penurunan Signal-to-Noise Rasio (SNR). Menurut Fruehwald-Pallamar et al., (2012) dengan 
menggunakan nilai acceleration factor 2 dan 3 pada teknik parallel imaging dapat menghasilkan citra yang baik dan waktu pemeriksaan yang lebih cepat. Disisi lain, menurut Blaimer et al., (2006) nilai acceleration factor 4 lebih banyak digunakan pada MRI kepala dan menghasilkan citra yang baik dengan scan time yang lebih cepat, tetapi pada penelitian ini peneliti ingin melakukan percobaan dengan menerapkan nilai acceleration factor 4 pada pemeriksaan MRI Lumbal dengan kasus HNP. Teknik GRAPPA (Generalized Autocalibrating Partially Parallel Acquisitions) merupakan salah satu metode yang digunakan untuk merekontruksi data pada teknik parallel imaging MRI. Teknik ini didasarkan pada korelasi dalam data yang diperoleh dari tampilan multi-coil dari modalitas MRI. Kosep GRAPPA diperkenalkan oleh Griswold pada tahun 2002 dengan menghasilkan kualitas gambar yang lebih baik secara keseluruhan (Schneider \& Matthias, 2008). Di RSUD Soedono Madiun pemeriksaan MRI lumbal dengan kasus HNP menggunakan teknik parallel imaging metode GRAPPA, dimana pada metode GRAPPA mengatur acceleration factor 2. Tetapi pada penggunaannya nilai acceleration factor ditentukan oleh banyaknya elemen coil yang dipakai (Siemens, 2003). Pada metode parallel imaging GRAPPA dapat dilakukan pemilihan acceleration factor yang apabila nilainya dinaikkan dapat mempercepat waktu pemeriksaan (scan time) (Fast \&Goldsher, 2007). Berdasarkan latar belakang tersebut peneliti tertarik untuk melakukan penelitian dengan tujuan untuk mengetahui adakah perbedaan penerapan acceleration factor terhadap karakteristik citra diagnostik yang dihasilkan dan mengetahui acceleration factor optimal pada teknik parallel imaging metode GRAPPA pada T2WI FSE kasus Herniated Nucleus Pulposus (HNP).

\section{Metode}

Populasi dari penelitian ini adalah seluruhcitra MRI Lumbal dengan kasus HNP. Jumlah sampel dari penelitian ini berdasar pada penentuan jumlah sampel yang dikembangkan oleh Roscoe (Sugiyono, 2010), bahwa untuk penelitian eksperimen dan kelompok control maka jumlah anggota sampel masing-masing antara 10 sampai dengan 20. Maka peneliti menggunakan 10 pasien sebagai sampel dari dua kelompok sampel berpasangan citra MRI Lumbal dengan kasus HNP, penggunaan GRAPPA dengan variasi acceleration factor 2, 3 dan 4 pada T2WI FSE MRI lumbal potongan sagital.
Prosedur pembuatan citra sebagaimana Prosedur Pemeriksaan MRI Lumbal kasus Herniated Nucleus Pulposus di Instalasi Radiologi Rumah Sakit dr. Soedono Madiun JawaTimur.

a. Memberikan penjelasan kepada pasien tentang pemeriksaan yang akan dilakukan termasuk lamanya waktu pemeriksaan.

b. Melepaskan semuabarang yeng bersifat feromagnetik dan bila perlu mengganti pakaian dengan pakaian khusus yang disediakan

c. Memasukkan data pasien kekomputer dan memilih sekuen yang digunakan.

d. Menyiapkan spine coil

e. Pasien diposisikan supine diatas meja pemeriksaan dengan MSP tubuh pasien berada dipertengahan meja pemeriksaan

f. Pasien diposisikan dengan sinar garis longitudinal berada pada MSP dan sinar garis horizontal setinggi L4

g. Strap dan pengganjal dapat digunakan sebagai imobilisasi bila diperlukan.

h. Setelah setelah memposisikan pasien selesai pintu ditutup rapat agar tidak adai nterferensi dari luar.

i. Mengisi data pasien. Data tersebut meliputi nama pasien, umur, jenis kelamin, nomor register, berat badan ( dalam satuan kilogram), tinggi badan (dalam satuan meter ), jenis pemeriksaan, nama dokter pengirim dan nama dokter ahli radiologi pada computer konsul MRI.

j. Membuat lokaliser daripotongan sagital dan menjalakan protocol rutin HNP pada RSUD Dr. Soedono Madiun. Sekuen yang digunakan Localizer, T2WI FSE sagital, TIWI FSE sagital, T2WI haste myelo coronal, T2WI myelosagital dan T2WI FSE transversal. Denganacceleration factor 2 metode GRAPPA.

k. Selanjutnya melakukan copy sekuen T2WI FSE sagital dengan acceleration factor 3 dan 4

1. Dalam pembuatan sekuen T2WI FSE sagital harus mempertimbangkan variable terkontrol denganTR : 3800, TE: 110, slice thickness: 4 mm FOV: 300 x 300 .

$\mathrm{m}$. Kemudian dilakukan penyimpanan citra MRI pada kaset DVD-R sesuai protokol yang telah ditetapkan.

Prosedur Penilaian Citra dilakukan oleh dua dokter spesialis radiologi diminta untuk mencermati citra MRI Lumbal kasus HNP yang telah disiapkan dengan tidak disertakan keterangan apapun baik identitas pasien maupun parameter yang digunakan dan hanya diberi kode seri citra. Penilaian dokter spesialis radiologi untuk informasi citra dilakukan dengan memberikan 
tanda cek (v) pada kuisioner yang disediakan sesuai dengan petunjuk. Kuisioner berisi penilaian terhadap informasi citra anatomi. Kemudian hasil kuesioner berupa angka yang akan diolahmenggunakan Visual Grading Analysis (VGA) dan Visual Grading Characteristic (VGC).

Data hasil kuisioner yang diperoleh dari hasil ekspertise dua dokters pesialis radiologi terhadap 30 citra dengan 3 variasi acceleration factoryaitu 2, 3 dan 4. Data diolah dan diuji secara komputerisasi menggunakan analisa VGA untuk mengetahui ada perbedaan atau tidak pada penggunaan ketiga acceleration factor tersebut. Dari hasil VGA dengan mengggunakan rumus :

$$
\operatorname{VGAS}=\frac{\sum_{o, i} S c}{N_{i} N_{o}}
$$

Keterangan : $\mathrm{Sc}=$ untuk observer $(\mathrm{O})$ dangambar $(\mathrm{I}), \mathrm{Ni}=$ totaljumlahdarigambar, No $=$ total jumlahdari observer

\section{Hasil dan Pembahasan}

Tabel 1. Deskripsi Sampel Berdasarkan Umur

\begin{tabular}{lll}
\hline Umur & Jumlah & Presentase \\
\hline $36-45$ & 2 & $20 \%$ \\
$46-60$ & 6 & $60 \%$ \\
$>60$ & 2 & $20 \%$ \\
Jumlah & 10 & $100 \%$ \\
\hline
\end{tabular}

Berdasarkan table tersebut dapat diketahui bahwa penelitian ini menggunakan 10 pasien dengan rentang usia 36-45 tahun berjumlah 2 pasien, 46-60 tahun berjumlah 6 pasien dan pasien dengan rentang usai lebih dari 60 tahun berjumlah 2.

Setiap hasil image dari pasien tersebut dihasilkan 3 gambar pada potongan sagital sekuen FSE dengan 3 variasi acceleration factor, salah satu hasil citra dari variasi acceleration

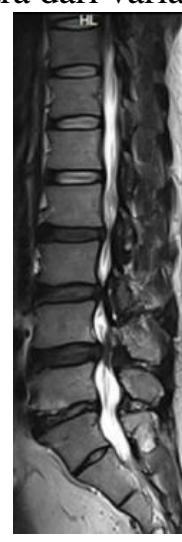

(a)

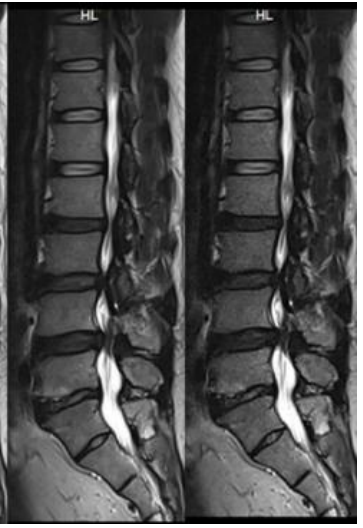

(b) (c)
Gambar 1. Citra MRI Lumbal acceleration factor 2 (a) acceleration factor 3 (b) acceleration factor 4 (c)
Tabel 2. Tabel Frekuensi dari hasil pemeilihan garding oleh observer pada penerapan penggunaan $\mathrm{AF}(2,3$ dan 4)

\begin{tabular}{llll}
\hline \multirow{4}{*}{ Grade } & \multicolumn{3}{l}{ Number of Decision } \\
& AF $\mathrm{G}_{-}$AF & AF G_4 \\
\hline 1 & 2 & G_3 & \\
2 & 30 & 30 & - \\
3 & 10 & 10 & 10 \\
4 & 10 & 10 & 20 \\
5 & - & - & 20 \\
\hline Keterangan : & - & - & - \\
AF G & $:$ Acceleration Factor GRAPPA \\
GRAPPA & $:$ GeneRillzed Autocalibrating \\
& Partialy Parallel Acquisition \\
Grade 1 & $:$ Sangat bagus \\
Grade 2 & $:$ Bagus \\
Grade 3 & $:$ Cukup \\
Grade 4 & $:$ Terbatas \\
Grade 5 & $:$ Buruk
\end{tabular}

Perhitungan menggunakan perhitungan VGA tersebut diperoleh grafik sebagai berikut:

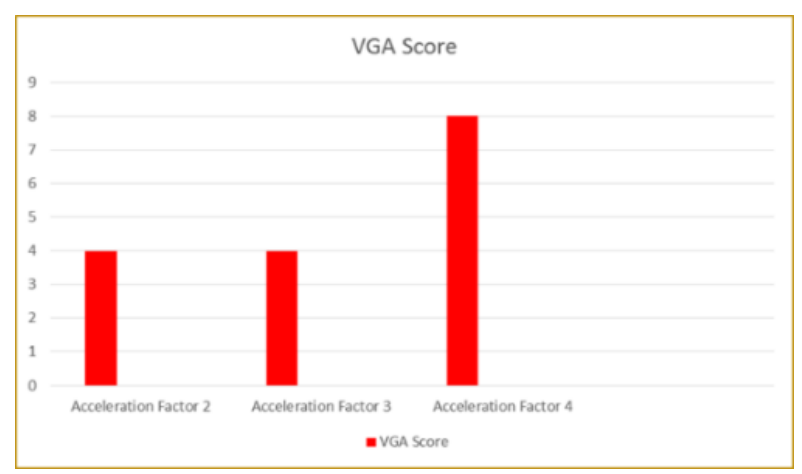

Gambar 2. Hasil Visual Grading Score pada penilaian setiap kriteria anatomi yang dinilai observer

Berdasarkan skala yang digunakan yaitu dengan rentang nilai $1-5$, dimana semakin besar angka yang dipilih maka kualitas citra yang dihasilkanakan semakin buruk dan sebaliknya, apabila semakin kecil angka yang dihasilkan pada penilaian kuesioner maka citra yang dihasilkan semakin baik citra yang dihasilkan. Hasil perhitungan VGA ditunjukan dengan grafik 1 . Yakni angka tertinggi 8 pada penggunaan acceleration factor 4, yang artinya citra yang dihasilkan buruk atau diperlukan pengulangan untuk dapat mendiagnosa suatu penyakit HNP.Sedangkan acceleration factor 2 dan 3 mendapatkan nilai paling rendah yakni 4 yang diartikan bahwa acceleration tersebut dapat digunkaan untuk mendiagnosa pasien dengan kasus HNP.

Berdasarakan pemilihan grading oleh observer pada kelima kriteria anatomi yakni corpus vertebrae, discus intervertebralis, canalis spinalis, 
spinal cord dan nucleus pulposus dalam penerapan accleration factor 2, 3 dan 4 dalam tabel 3 diketahui bahwa karakteristik citra diagnostik pada acceleration factor 2 dan 3 parallel imaging metode GRAPPA menghasilkan karakteristik citra diagnostik yang sama pada kasus Herniated Nucleus Pulposus (HNP). Acceleration factor 2 dan 3 mendapatkan rentang penilaian grading image 10 hingga 30 oleh observer dalam menghasilkan karakteristik citra diagnostik. 30 menunjukan jumlah nilai grading oleh observer yang diperoleh dari 10 citra yang dihasilkan pada masing-masing penerapan acceleration factor 2 dan 3 yang dinyatakan sangat baik, sedangkan pada penerapan acceleration factor 4 diperoleh jumlah rentang penilaian dari skala 10 hingga 20 dalam menghasilkan karakteristik citra diagnostik kasus Herniated Nucleus Pulposus (HNP) dengan jumlah nilai grading sebanyak 10 yang menyatakan bagus menunjukkan jumlah nilai grading oleh observer yang diperoleh dari 10 citra yang dihasilkan pada penerapan acceleration factor 4, 20 dinyatakan cukup yang diproleh dari jumlah nilai grading oleh observer yang diperoleh dari 10 citra yang dihasilkan pada penerapan acceleration factor 4, sedangkan 20 dinyatakan terbatas yang diperoleh dari 10 citra yang dihasilkan pada penerapan acceleration factor. 10 citra dinyatakan bagus, 20 citra dinyatakan cukup dan 20 citra dinyatakan terbatas, dari tabel 3 untuk mendapatkan VGC cuve yang digunakan untuk menganalisa hasil penerapan acceleration factorparallel imaging metode GRAPPAyang optimal diperlukan VGC data point terebih dahulu guna mendapatkan titik-titik dalam pembuatan VGC curve sehingga diperlukan pembuatan tabulasi data untuk mendapatkan VGC data point .VGC curve dapat diperoleh dengan membuat ROC curve terlebih dahulu, data point yang dihasikan digunakan dalam pembuatan ROC curve yang nantinya menjadi hasil akhir dari VGC curve yang disertai perolehan AUC( Area Under Curve) yang diketahui setelah pembuatan ROC curve. Pembuatan ROC curve dibutuhkan karena memang hasil dari VGC curve membutuhkan ROC curve dalam menganalisa hasil penerepan acceleration factor 2, 3 dan 4. Curve pertama perbandingan acceleration factor 2 dan 4dengan ordinat curve (sumbu y) adalah acceleration factor 2 dan absis curve (sumbu $\mathrm{x}$ ) adalah acceleration factor 3 . Curve kedua perbandingan acceleration factor 2 dan 4dengan ordinat curve (sumbu y) adalah acceleration factor 2 dan absis curve (sumbu $\mathrm{x}$ ) adalah acceleration factor 4. Curve pertama perbandingan acceleration factor 3 dan 4 dengan ordinat curve (sumbu y) adalah acceleration factor 2 dan absis curve (sumbu $\mathrm{x}$ ) adalah acceleration factor 4

Untuk memperoleh kurva VGC maka tabel 3 dilanjutkan menggunakan tabel VGC data point atau perolehan pasangan nilai VGC pada tabel 4 . Hasil dari tabel 4 tersebut diperoleh dari akumulasi tiap-tiap grading dibagi dengan keseluruhan jumlah pasien pada penelitian (10) dan dikali dengan jumlah kriteria anatomi (5) yang dinilai oleh observer. Maka dapat diperoleh perhitungan VGC pada tiap penerapan acceleration factor metode GRAPPA yang ditujukan pada kolom VGC pada tiap acceleration factor. Setelah diperoleh nilai VGC maka nilai dari masing-masing acceleration factor (AF) diolah dengan menggunakan ROC (Receiver Operating Caracteristic) curve. ROC curve adalah proses untuk mendapatkan Area Under Curve (AUC) dengan hasil akhir yang digunakan untuk mengetahui penerapan acceleration factor yang terbaik. VGC curve pada penelitian ini dibuat melalui ROC analisis menggunakan kalkulasi berbasis web yang telah dikembangkan oleh John Eng, M.D dan Russell H. Morgen di departemen radiologi dan ilmu radiologi, Johns Hopkins University, Baltimore, MD, USA ( dapat diakses secara online

http://www.rad.jhmi.edu/jeng/javarad/roc/JROCFI $\underline{\text { Ti.html) }}$

Selanjutnya untuk mengetahui nilai optimal dilakukan uji Visual Grading Characteristic (VGC) untuk mengetahui nilai acceleration factor optimal dalam mengahsilkan citra karakterisitik diagnostik kasus HNP.

Tabel 3. Hasil perhitungan VGC data point pada tiap acceleration factor

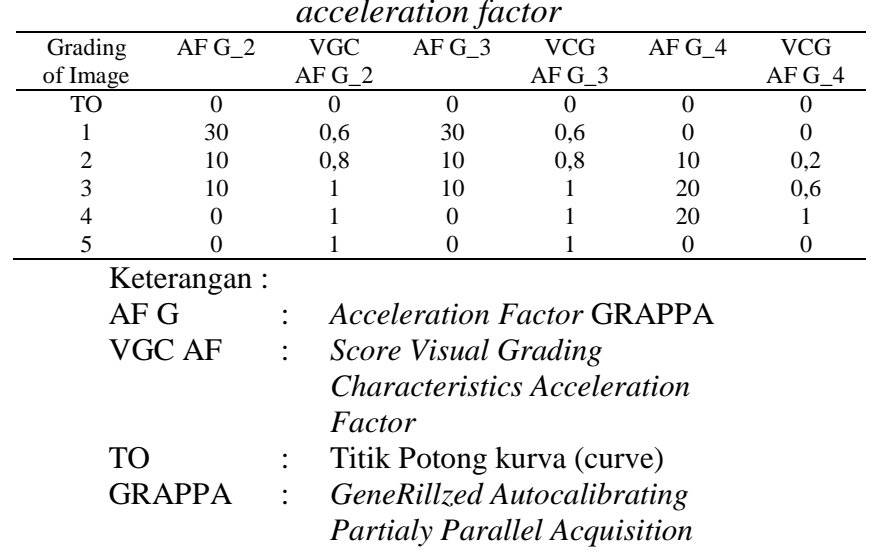

\footnotetext{
Grading Of image

1 : Sangat baik

2 : Bagus

3 : Cukup
} 
$4:$ Terbatas

5 : Buruk

Diperoleh perhitungan seperti tabel 4 untuk mendapatkan ROC curve beserta Area Under Curve (AUC) dengan menggunakan aplikasi web akan diperoleh ROC curve sebagi berikut:

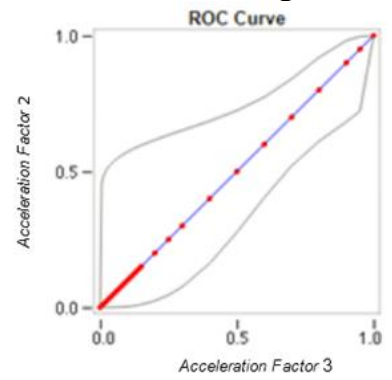

Gambar 3. ROC Curve penerapan acceleretion factor 2 dan 3 metode GRAPPA

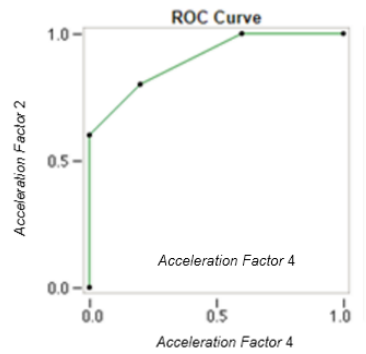

Gambar 4. ROC curve penerapan acceleretion factor 2 dan 4 metode GRAPPA

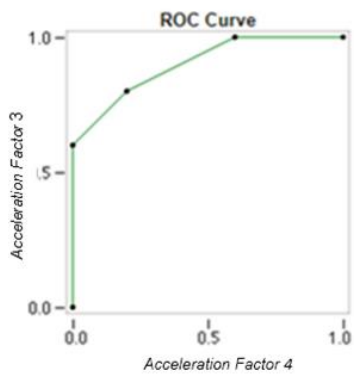

Gambar 5. ROC curve penerapan acceleration factor 3 san 4 metode GRAPPA

Tabel 4. Nilai AUC dari ROC curve pada masingmasing penerapan acceleration factor metode GRAPPA Keterangan :

\begin{tabular}{|c|c|c|}
\hline $\begin{array}{l}\text { Penerapan } \\
\text { factor GRAP }\end{array}$ & $\begin{array}{l}\text { acceleration } \\
P A\end{array}$ & Nilai $A U C$ \\
\hline 2 dan 3 & & 0,50 \\
\hline 2 dan 4 & & 0,92 \\
\hline 3 dan 4 & & 0,92 \\
\hline$\overline{\mathrm{AUC}}$ & \multirow{2}{*}{\multicolumn{2}{|c|}{$\begin{array}{l}\text { Area Under Curve } \\
\text { : GeneRillzedAutocalibrating Partialy } \\
\text { Parallel Acquisition }\end{array}$}} \\
\hline GRAPPA & & \\
\hline ROC & Receiver Ope & ating Caracteristic \\
\hline
\end{tabular}

ROC : Receiver Operating Caracteristic
Area Under Curve (AUC) dapat digunakan untuk mendiskripsikan penelitian ini dengan pengertian bahwa apabila AUC bernilai 0.5 (diagonal) kedua variasi tersebut dinilai sama baiknya, jika luasnya lebih besar dari 0.5 (di atas diagonal), variasi acceleration factor grappa A memiliki kinerja lebih baik dari pada B, dan prosedur akan dikatakan akurat akan menghasilkan kurva lebih dekat menuju sudut kiri atas. (Båth \& Månsson, 2007).

Dapat dilihat dari tabel 4 yakni grade tiap acceleration factor selalu dimulai angka 0. Angka 0 ini diartikan sebagai titik potong curve pada ROC curve yang dihasilkan. Setelah mengetahui AUC pada tiap curve maka akan diketahui acceleration factor yang terbaik pada tiap citra yang dihasilkan oleh acceleration factor (AF) 2,3 dan 4. ROC curvedapat diketahui bahwa nilai AUC acceleration factor 2 dan 3 adalah 0,5, dengan hasil tersebut dapat diketahui bahwa keduanya dinilai sama baiknya dalam menghasilkan suatu karakteristik citra diagnostik. Sedangkan AUC yang dihasilkan oleh acceleration factor 2 dan 4 metode GRAPPA adalah 0,92. Nilai AUC tersebut lebih dari 0,5 maka dapat diketahui bahwa acceleration factor 2 lebih baik dari pada acceleration factor 4, dan AUC yang dihasilkan oleh acceleration factor 3 dan 4 metode GRAPPA adalah 0,92. Hasil tersebut lebih dari 0,5 maka dapat dikatahui bahwa acceleartion factor 3 lebih baik dari pada 4 dalam menghasilkan citra diagnostik.

Perbedaan karaktersitik citra diagnostik T2WI FSE GRAPPA pada penerapan variasi nilai acceleration factor MRI lumbal potongan sagital pada kasus Herniated Nucleus Pulposus (HNP)

Citra karakteristik acceleration factor 2 parallel imaging metode GRAPPA potongan sagital menghasilkan karakteristik citra diagnostik yang dinyatakan sangat baik, terlihat discus intervertebare menampakkan adanya penyempitan dengan jelas, disc berisi minyak nukleus pulposus yang menghasilkan intensitas sinyal yang tinggi pada T2WI dapat dilihat dengan jelas. Acceleratioan factor 2 parallel imaging metode GRAPAA dengan sekuen T2WI FSE memperjelas pada gambaran annulus fibrosis disertai thin dark ring yang tampak dengan sinyal rendah apabila terjadi HNP (Herniated Nucleus Pulposus).

Menurut Catherin (2014) T2WI terdapat citra thin dark ring yang merupakan discus intervertebralis yang tampak dari anterior. Kehilangan $70 \%$ cairan di discus menyebabkan 
pengurangan sinyal pada sekuen T2W1. Degenerated disc dapat terlihat gelap dibandingkan discus sekitarnya sehingga dapat terlihat bulging atau hernia dan sangat jelas dilihat pada T2WI sagital, canalis spinalis tampak dengan sangat baik sehingga dapat memeperlihatkan adanya peneyempitan yang menyebabkan penekanan struktur syaraf yang berjalan didalamnya, spinal cord tampak dengan jelas. Spinal Cord tampak keabu-abuan intermediate, sinyal homogen dan lebih gelap dibandingkan dengan CSF dapat terlihat dengan jelas pada penggunaan acceleration factor 2 parallel imaging metode GRAPPA pada sekuen T2WI FSE. Adanya lesi pada cord akan tampak jelas pada potongan sagital dan nucleus pulposus dapat menampakkan dengan jelas adanya herniasi nucleus pulposus yaitu ditandai pada citra MRI dengan acceleration factor 2 parallel imagingmetode GRAPPA dapat terlihat dengan jelas adanya penonjolan pada beberapa nucleus pulposus yang menyebabkan Herniated Nucleus Pulposus (HNP). Keseluruhan citra yang dihasilkan pada acceleration factor 2 bagus tanpa adanya noise yang mengganggu pada penegakan diagnosa HNP, sehingga observer dapat mengetahui secara tepat letak Herniated Nucleus Pulposus (HNP) yang dialami pasien. Acceleration factor 3 parallel imaging metode GRAPPA menghasilkan citra karakteristik yang relatif sama dengan acceleration factor 2 dapat dilihat dari corpus vertebrae yang jelas. Kejelasan tersebut dapat terlihat dengan tampaknya sinyal yang tinggi dari bone marrow, discus intervertebrae dapat memperlihatkan penyempitan dengan jelas, canalis spinalis dapat menampakkan dengan jelas adanya penekanan yang terjadi, spinal cord tampak dengan jelas dan nucleus pulposus dapat menampakkan degan jelas adanya herniasi nucleus pulposus sehingga dapat memeberikan diagnosa secara tepat letak Herniated Nucleus Pulposus (HNP) pasien dan tidak terdapat noise pada hasil citra MRI. Accelereation factor 4 parallel imaging metode GRAPPA menunjukkan karakteristik citra diagnostik yang berbeda dengan accleration factor 2 dan 3. Perbedaan ini dapat dilihat dari ketidak jelasan pada semua anatomi seperti corpus vertebrae, discus intervertebrae, canalis spinalis, spinal cord dan nucleus pulposus menunjukkan adanya noise. Sehingga terjadi keterbatasan informasi yang menyebabkan obsrever mengalami kesulitan untuk mengetahui secara tepat letak herniasi yang dialami oleh pasien penderita Herniated Nucleus Pulposus (HNP).

Hal yang menyebabkan perbedaan terhadap karakteristik citra diagnostik tersebut adalah penggunaan acceleration factor yang lebih tinggi dalam metode pencitraan parallel imaging biasanya diikuti dengan penurunan signal-to-noise rasio (SNR) (Blaimer et al., 2006). Sehingga apabila dilakukan penambahan acceleration factor akan mengakibatkan penurunan SNR yang mengakibatkan berkurangnya kejelasan informasi yang dibutuhkan radiolog dalam menilai suatu citra MRI untuk menegakkan diagnosa yakni khususnya pada kasus Herniated Nucleus Pulposus (HNP) .

Siemens (2004) menyatakan bahwa langkahlangkah phase-encoding dapat dihilangkan dengan mengaplikasikan iPAT atau parallel imaging untuk mempercepat akuisisi data dengan rekonstruksi khusus yang digunakan untuk mempertahankan resolusi citra. GRAPPA dapat merekonstruksi baris phase-encoding diukur yang hilang sebelum transformasi Fourier karena adanya baris referensi yang terukur. Baris referensi yang dimaksud adalah baris yang mengisi beberapa langkahlangkah phase-encoding yang hilang sehingga SNR dapat tetap terjaga. Meskipun demikian dalam penelitian ini GRAPPA ternyata memiliki keterbatasan dalam memperbaiki resolusi citra pada penerapan acceleration factor 4 teknik parallel imaging metode GRAPPA. Metode GRAPPA mampu memperbaiki resolusi citra, namun penurunan SNR pada penerapan acceleration factor 4 tersebut tidak dapat ditoleransi lagi. Hal tersebut merupakan kompensasi dari penggunaan acceleraration factor yang semakin meningkat akan mengurangi SNR.

\section{Nilai Optimal Acceleration Factor parallel imaging metode GRAPPA untuk menghasilkan karakteristik citra diagnostik pada pencitraan MRI sekuen T2WI FSE sagital kasus Herniated Nucleus Pulposus (HNP).}

Pada pengujian acceleration factor 2, 3 dan 4 menggunakan uji VGC curve menunjukkan penggunaan acceleratioan factor 2 dan 3 parallel imaging metode GRAPPA memiliki karakteristik citra diagnostik sama baiknya, sedangkan pada acceleratioan factor 4 menghasilkan karakteristik citra diagnostik tidak sebaik pada acceleration factor 2 dan 3. Masing masing acceleration factor ini menghasilkan waktu scan yang berbeda-beda yakni acceleration factor 2 membutuhkan waktu 2,34 menit, acceleration factor 3 membutuhkan waktu 1,48 menit dan acceleartion factor 4 membutuhkan waktu 1,25 menit dalam menghasilan citra MRI pada sekuen T2WI FSE potongan sagital. Perbedaan waktu ini disebabkan oleh penggunanaan acceleratioan factorparallel imaging. Pernyataan tersebut diperkuat dengan 
adanya pernyataan Runge (2014) yang menyatakan parallel imaging khususnya pada penggunaan acceleration factor biasanya digunakan untuk mengurangi waktu akuisisi MRI dengan kerugian pada rasio signal-to-noise (SNR) dengan memungkinkan lebih cepat dan kualitas yang lebih tinggi (perbaikan resolusi spasial dan SNR).Diperkuat pula padapernyataanBlaimer\& $\mathrm{Al}$ (2004) yang menyatakanacceleration factor ( $\mathrm{R}$ factor) ini menyatakan jumlah elemen phased array coils yang akan mempengaruhi scan time (Blaimer \& Al, 2004).

Acceleration factor 3 mampu menghasilkan suatu citra yang sama baiknya dengan acceleration factor 2 dengan membutuhkan waktu yang lebih singkat. Baert (2007) mengatakan bahwapencitraan parallel imaging biasanya digunakan untuk mengurangi waktu akuisisi MRI dengan kerugian pada rasio signal-to-noise (SNR). Penggunaan acceleratioan factor 3 parallel imaging metode GRAPPA tidak menunjukkan SNR yang signifikan. Namun pada penerapan acceleratioan factor 4 sudah tidak mampu menapakkan kejelasan karakteristik citra diagnostik pada kasus Herniated Nucleus Pulposus (HNP), ketidak jelasan ini disebabkan adanya noise yang timbul akibat penurunan SNR terlihat begitu jelas, menyebabkan observer sangat kesulitan dalam menilai citra MRI pada kasus Herniated Nucleus Pulposus (HNP).

Menurut Nael (2006), accelereration factor GRAPPA naik maka kualitas citra akan menurun, jadi dengan meningkatkan acceleration factor GRAPPA maka langkah phase encoding akan dipercepat sesuai acceleration factor yang digunakan karena sampling yang mengisi semua kspace tidak terisi secara penuh. Ketika k-space tidak terisi penuh maka akan mengumpulkan sedikit phase encoding spin echo. Akan terjadi pengurangan data linear yang dicatat dalam satu waktu akuisisi citra, karena waktu akuisisi data citra dan data citra sebanding dengan pengumpulan jumlah echo dari phase encoding.

Penggunan acceleration factor tenyata mempunyai batas tertentu dalam mencitrakan suatu gambar MRI, pada penelitian ini diketahui capaian acceleration factor 4 metode GRAPPA sudah tidak mampu lagi untuk menampilkan citra yang optimal, dikarenakan menghasilkan noise yang tampak jelas dan hampir seluruh anatomi yang tampak dikelilingi noise pada citra MRI lumbal potongan sagital yang dihasilkan.

Hasil penelitian ini dapat diketahui bahwa penggunaan acceleration factor 3 parallel imaging metode GRAPPA dapat digunakan sebagai referensi dalam penerapan pada pasien-pasien yang menderita Herniated Nucleus Pulposus (HNP). Pasien yang menderita HNP secara umum tidak mampu menahan rasa sakit yang dideritanya sehingga memerlukan waktu pemeriksaan yang cepat, setidaknya acceleration factor 3 mampu mengurangi waktu pencitraan MRI lumbal atau dapat dikatakan memilki scan time yang lebih cepat dibandingan dengan menggunakan accelration factor 2. Sedangakan metode GRAPPA dapat mendukung pemeriksaan HNP karena dengan kenaikan acceleration factor mampu memperbaiki SNR yang turun selain itu metode GRAPPA tidak terlalu sensitif dalam pergerakan dan GRAPPA menghasilkan SNR yang baik dalam menghasilkan citra (Ruel, 2004) sehingga apabila pasien dengan kasus HNP mengalami sidikit pergerakan rekontruksi citra tidak akan terganggu dan karakteristik citra diagnostik yang dihasilkan tetap optimal. Sedangkan acceleration factor 4 parallel imaging metode GRAPPA dari hasil penelitian ini tidak mampu memberikan karakteristik citra diagnosa sebaik acceleration factor 2 dan 3 pada kasus HNP pada pemeriksaan MRI lumbal T2WI FSE potongan sagital. Observer menilai acceleration factor 4 terlalu banyak noise sehingga terbatas dalam menilai informasi yang terkandung pada citra MRI yang dihasilkan. Dapat dikatakan penerapan acceleration factor 4 tidak dapat digunakan untuk pemeriksaan MRI lumbal kasus Herniated Nucleus Pulposus dikarenakan tidak informatif dalam menghasilkan karakteristik citra diagnostik.

\section{Simpulan}

Berdasarkan hasil penelitian dan pembahasan dapat disimpulkan bahwa Ada perbedaan dalam menghasilkan karakteristik citra diagnostik MRI lumbal potongan sagital sekuen Fast Spin Echo (FSE) dengan perbedaan penerapan acceleration factor pada kasus Herniated Nuceleus Pulposus (HNP) dengan variasi acceleration factor 2, 3 dan 4 dengan hasil nilai VGA yang berbeda-beda yang berarti ada perbedaan karakteristik citra diagnostik yaitu pada anatomi corpus vertebrae, discus intervertebralis, canalis spinalis, spinal cord dan nucleus pulposus. Nilai acceleration factor yang optimal pada pemeriksaan MRI kasus HNP adalah acceleration factor 2 dan 3 


\section{Daftar Pustaka}

Brown, M. A., \&C.Samelka, R. MRI Basic Principle and Applications. (J. W. and S. Inc, Ed.). New Jersy. 2015.

Bushong. Magnetic Resoance Imaging: Physical and Biological Principle (Fourth Edi). Texas, USA: The University of Texas Health Science Center at San Antonio San Antonio, Texas. 2015.

Bushong. MAGNETIC RESONANCE IMAGING : PHYSICAL AND BIOLOGICAL PRICIPLE (Fourth Edi). USA: The University of Texas Health Science Center at San Antonio San Antonio, Texas. 2015.

Catherine, W. Westbrook - Handbook OfMri Technique.pdf. Blackwell Science Ltd.: United Kingdom. 2014.

D'Antoni, A. V. Gray's Anatomy. The Anatomical basis of clinical practice. Clinical Anatomy. 2016.

Dale, M.Brian, M.A, B., Richard, C., \&Sememlka. MRI Basic Principle and Applications (Fifth Edit). : New Jersey: John Wiley and Sons Inc. 2015.

Fruehwald-Pallamar, J., Szomolanyi, dkk. Parallel imaging of the cervical spine at 3T: Optimized trade-off between speed and image quality. American Journal of Neuroradiology, 33(10), 1867-1874. 2012.

Hidayat, A. A. . Metode Penelitian Kebinanan \& Teknik Analisis Data. Jakarta: Salemba Medika. 2011.

Ludewig, E., Richter, A., \& Frame, M. Diagnostic imaging - Evaluating image quality using visual grading characteristic (VGC) analysis. Veterinary Research Communications. 2010, 34(5), 473-479.

Matt A. Bernstein, K. F. K. (n.d.). HandBookOf MRI Pulse Sequences. United Kingdom: University of Illionis of any medical equipment manufacture.

Moeller. MRI Parameters and Positioning. Orbit An International Journal On Orbital Disorders And Facial Reconstructive Surgery (Vol. 512). 2013.

Moore, K., Dalley, A., Agur, A., \& More, M. Anatomi berorientasi klinis (Edisi ke 5). Jakarta: Erlangga. 2013.

Noor, H., \&Zairin. Buku Ajar Gangguan Muskuloskeletal (Jilid 1). Jakarta: Salemba Medica. 2012.

Runge, R, W., \&Trelles, M. The Physics of Clinical MR Taught Through Images (Third
Edit). New York: Thieme Medical Publisher. 2014.

Schneider, \& Matthias. GPGPU for Accelerated GRAPPA Auto Calibration in Magnetic Resonance Imaging. 2008.

Wang, \& Al, H. e. Cross-Sampled GRAPPA for Parallel MRI. USA: University of Wisconsin. 2010.

Westbrook, C., Roth, C. K., \& Talbot, J. MRI IN PRACTICE. 2011.

Westbrook, Chaterine, \&Kaut, C. MRI in Practice, Fouth Edition. United Kingdom: Blackwell Science Ltd. 2011. 